Meta

Journal des traducteurs

Translators' Journal

\title{
Challenges in Minority Langage programming in Canada's Eastern Arctic: The Training of Aboriginal Language Interpretor-Translators
}

\section{Susan Sammons}

Volume 38, numéro 1, mars 1993

La traduction et l'interprétation dans le nord du Canada

Translation and Interpretation in Northen Canada

URI : https://id.erudit.org/iderudit/004023ar

DOI : https://doi.org/10.7202/004023ar

Aller au sommaire du numéro

Éditeur(s)

Les Presses de l'Université de Montréal

ISSN

0026-0452 (imprimé)

1492-1421 (numérique)

Découvrir la revue

Citer cet article

Sammons, S. (1993). Challenges in Minority Langage programming in Canada's Eastern Arctic: The Training of Aboriginal Language Interpretor-Translators. Meta, 38(1), 45-50. https://doi.org/10.7202/004023ar
Résumé de l'article

On explique les raisons de la création de l'Arctic College. On présente l'organisation externe et interne du collège, plus spécifiquement la structure du programme d'interprétation et de traduction (conditions d'admission, contenu des cours, etc.). On fait le bilan des deux premières années de fonctionnement. 


\title{
CHALLENGES IN MINORITY LANGUAGE PROGRAMMING IN CANADA'S EASTERN ARCTIC: THE TRAINING OF ABORIGINAL LANGUAGE INTERPRETER-TRANSLATORS
}

\author{
SUSAN SAMMONS \\ Arctic College, Iqaluit,
}

Northwest Territories, Canada

\begin{abstract}
Résumé
On explique les raisons de la création de l'Arctic College. On présente l'organisation externe et interne du collège, plus spécifiquement la structure du programme d'interprétation et de traduction (conditions d'admission, contenu des cours, etc.). On fait le bilan des deux premières années de fonctionnement.
\end{abstract}

\begin{abstract}
This article explains the reasons which led to the creation of Arctic College and presents its external and internal structure and more specifically, the programmes of interpretation and translation (eligibility, course contents, etc.). It gives an account of the first two years of its functioning.
\end{abstract}

Canada is composed of ten provinces and two territories, the Yukon and the Northwest Territories. The Northwest Territories, which has a land mass of 3,244,608 square kilometers, covers the top third of Canada. It has a population of approximately 50,000 people composed of Inuit, Dene, Metis and Euro-Canadians. The majority of Dene and Metis people speak Athapaskan languages including Dogrib, Chipewyan, South Slavey, North Slavey and Gwich'in. The Inuit speak Inuktitut, a member of the Eskimo-Aleut language family.

Educational levels in the NWT are lower than anywhere else in Canada. An estimated 10,600 or $36 \%$ of all residents over 15 years of age have less than grade nine education. Among the aboriginal population the statistics are even more dismal: $63 \%$ have less than a ninth grade education (Arctic College 1990). These low levels of scholarity inevitably lead to high unemployment rates.

The education system in the NWT is only just beginning to meet the needs of its residents. Since the early 1970's, the Department of Education has changed its predominantly assimilationist philosophy to one in which native culture and language have been recognized as being important and native language and cultural inclusion programs have been incorporated into the school curriculum. Two of the greatest obstacles to such programming continue to be the lack of qualified native teachers trained in language instruction and the lack of a developed Inuktitut curriculum and learning materials at all levels. However, schools are now controlled by locally elected community education councils or societies, and more children are finishing high school.

In 1982 a Special Committee of the NWT Legislative Assembly set up to study the entire educational system finished its final report entitled Learning: Tradition and 
Change in the Northwest Territories. One of their major recommendations was the development of a college system for the NWT to expand the role of the Adult Vocational Training Center which was established in 1969 at Fort Smith in the Western NWT.

As a result of this report, six campuses of Arctic College have been established since 1984 in major regional centres. In the smaller communities of each region, Adult Education Centres have been incorporated into the College system and renamed Community Learning Centres. These centres focus on literacy, adult basic education programs, deliver campus field based programs and feed students into the Certificate and Diploma programs offered in the major College facilities located in the regional centres.

At the campus level, both credit and non-credit courses are available. Credit programs include college and university preparation, literacy and basic education, introductory pre-employment apprenticeship, trades, business, environmental studies, health, human services, secretarial arts, teacher education and the interpreter/translator program.

Training in the field of interpretation and translation had previously been provided by the Interpreter Translator Corps (later known as the Language Bureau) of the Government Northwest Territories. Developments such as the election of unilingual aboriginals to the Legislative Assembly, the passage of the NWT Official Languages Act which ensures services will be available in the aboriginal languages as of January 1, 1991, and the amendment of the NWT Jury Act in September of 1989 allowing unilingual aboriginals the right to sit on juries, stretched the services of the Language Bureau to their limits and they found themselves in a position where they could no longer provide adequate training to the number of interpreter/translators needed to meet this increased demand for services.

To meet this demand for trained interpreter/translators, Arctic College established Interpreter/Translator Programs at two campuses in 1987. These programs were charged with the responsibility to provide post-secondary training in interpreting and translating between the aboriginal languages and English. In the eastern half of the territory, a program was set up at Nunatta Campus in Iqaluit to train students in Inuktitut and English interpretation and translation. In the west, a program was established at Thebacha Campus in Fort Smith to train students in several Dene languages and English interpretation and translation. Base funding was provided by the Department of Education to deliver the first year of the program.

\section{COURSE DESIGN}

At the onset, the program was designed to be two years in length, with two exit points. After successful completion of the first year, students could leave with a Certificate in Interpretation and Translation; and a second year of study led to a Diploma in Interpretation and Translation. The program was designed in this manner to accommodate students who, due to extended family responsibilities and/or others commitments, could not afford to be away from their communities for a two-year period. In southern Canadian schools of interpretation and translation, where applicants typically have several more years of formal education, students are not admitted into interpretation programs without first completing undergraduate degree programs in translation. It was noted that even after completion of the College's Diploma program, it would be necessary not to set unrealistically high expectations of the students' abilities.

\section{COURSE DELIVERY}

Course delivery was adapted to meet the different realities existing at the two campuses. Thebacha Campus adopted a modularized delivery of courses for both semesters of the first year of the program. Courses were taught either by the coordinator of the program or by contract instructors brought in from Yellowknife for two- to three-week periods. 
Due to the high cost of travel from Yellowknife, the capital of the NWT, where many language specialists are located, to Iqaluit ( $\$ 1500.00$ per round trip ticket compared with $\$ 240.00$ round trip Yellowknife/Fort Smith), it was decided that it would be more cost effective to hire two full-time staff for the Iqaluit program and to hire casuals on a limited basis where necessary. For the Iqaluit program, two instructors were hired, one whose first language was English, and one whose first language was Inuktitut.

It was decided to deliver the first term of the Iqaluit program on a semester-long basis for two reasons. First, it was possible to take advantage of existing cross-listed courses which were being offered by other College programs. Second, it was believed that the upgrading of language skills emphasized in the first term of the program would best be taught over time rather than through short, intensive modularized courses.

\section{ENTRANCE REQUIREMENTS}

A language proficiency test was incorporated into the program design. This was a test of student proficiency in both languages, English and Inuktitut. The written competency test comprised three writing assignments in each language. The oral test was designed to evaluate shadowing, memory recall and sight translation skills.

After piloting the original test, it became apparent that major revisions as to delivery were necessary. The program was designed to serve the needs of the Eastern half of the NWT, a huge, isolated area spanning $1500 \mathrm{~km}$ east to west and $1600 \mathrm{~km}$ from north to south. Many of the test packages which were mailed to designated test centres in the different communities took several weeks to arrive; one package was lost and had to be replaced. To speed up the evaluation process, the packages were returned to the program by air cargo, which proved both costly and ineffective - the turn-around time from some communities was two and a half weeks and once again one of the packages was lost, necessitating the rewriting of the test.

In order to streamline the admission process, the test was modified and the oral component was removed. This allowed us to send copies of the test by fascimile transmission to the College's Community Learning Centres where the tests were administred, all of which were equipped with fax machines. Telephone interviews conducted in both languages, which had previously been part of the admissions procedure, were expanded and provided insights into the students' level of oral language proficiency. Although less information was gathered in this manner, we found the admissions process much more efficient.

\section{8-1989}

During the first semester of program delivery in 1987, it became apparent that the program design, which had been primarily targeted at full-time students was not sufficiently well co-ordinated with other training and was not really meeting the needs of the interpreter/translator community in the Eastern Arctic.

A legal-interpreter training program had been established through the Department of Justice independent of the College program. After consultation with the co-ordinator of that program, it was agreed that the College program would incorporate the four twoweek legal modules into the first and second years of the College's Interpreter/Translator program. This ensured that students graduating from the College program would not have to undertake further training if they wished to pursue careers in legal interpreting. It also allowed trainees in the Department of Justice's program to receive College credits for courses completed.

Due to the small number of competent interpreters and translators in the NWT, their services are in high demand. Young native people who speak both an aboriginal language 
and English are often hired into high-paying positions without any training. This situation has an adverse effect on the program. There is little incentive for young bilinguals to enroll in full-time studies and live on small allowances when they could be making good money in full-time jobs, without training. This situation has led to low full time enrollments over the life of the program and will continue to do so until the Government and other agencies make either the completion of a training program or on-the-job training a mandatory condition of employment.

Because of this situation, the interpretation and translation courses offered in the second semester were revised to better meet the needs of part-time students. In the original program design, skills were taught using a variety of generic materials. In the Eastern Arctic, course materials were modified so that skills were still presented in levels of increasing difficulty but the materials were taught around six theme areas, education, social issues, government, environment, as well as medical and legal interpretation. Course content hours remained the same, skill development remained the same, but instructional materials focused on the different theme areas. The interpretation and translation courses in the diploma program were also adapted in this way. These modifications allowed interpreter/translators already employed in the field to attend short intensive courses of the program for two week durations, which concentrated on skill development and on increasing their knowledge of terminology in specific fields.

It was decided that part-time students would be admitted on the strength of their field experience and upon the recommendation of their supervisors. Some concern was expressed about the skill development of part-time students only attending two week modules of the course. This was monitored closely during the initial delivery. A second concern arose over how well the part-time students would integrate with the full-time students in the program.

Both of these concerns dissipated over the semester. Although many of the parttime students had lower academic levels than those accepted into full-time training, the depth of their experience proved sufficient to balance this out. The full-time students gained insights from part-time students who had actually worked in different areas of translation and interpretation.

Another weakness which was identified during the first year of operation was the difficulty in identifying reference material available in the native language, Inuktitut. This shortage of material was especially severe in the area of technical terminology. Although a bilingual weekly newspaper, magazines, and radio and TV programming exist, and although most government documents are available in both the aboriginal language and English, providing valuable resource materials, no dictionary or comprehensive word lists existed in Inuktitut. Staff and students in the interpreter/translator program collected existing word lists from individuals working in specialized fields. They added new terminology arising from the theme areas studied in the program and, in 1989, the Interpreter Translator program published its first Annual Word List Book.

\section{9-1990}

In the first year of operation, only seven out of seventeen applicants were accepted due to low scholarity. The others were advised to complete a year of upgrading in their home communities and reapply for the following year, of which two did. Of the seven who were admitted to the first year, only three completed the program. Of the four who withdrew, one left on the first day due to homesickness, one became pregnant, one left because of unresolved personal problems and one withdrew to enter an outfitting business with his brother. Eight part time students attended and all completed the course modules to which they had applied. 
The program statistics for the 1988-1989 academic year and the admission statistics for students for the 1989-1990 year led us to a number of disturbing conclusions. First, it would not be feasible to begin delivery of Diploma Program until 1991-1992, when it was projected that sufficient numbers of students would have completed the Certificate program. It was decided that we would deliver the Certificate program for three academic years, deliver the Diploma in the fourth year, and then return to Certificate delivery until such time as student numbers warranted the concurrent delivery of both programs.

Few married applicants from the outlying communities were admitted to or completed the program. The lack of married students accommodation and the overall housing crisis in Iqaluit, compounded by the fact that many potential students were unable to leave their communities due to work and family responsibilities or other commitments, led to few applicants from outlying communities being admitted to the program.

The cost of delivery of traditional field-based courses, where students from different locations and instructors are flown into an outlying community for intensive two- or three-week modules, was unrealistic in the prevailing climate of government fiscal restraint. Based on the experience of the Eastern Arctic Teacher Education Program's fieldbased operations, travel and accommodation were estimated at approximately $\$ 2,000.00$ per student for a three credit field-based course, or $\$ 40,000.00$ for each course enrolling 20 students (Wilman 87).

In order to reach students in outlying communities, two other delivery options were explored. In the first approach an introductory skills and methods course was designed to include daily lesson plans, materials, exercises and assignments in a highly-structured format. Letters were sent out to Community Learning Centres explaining that we would be willing to offer the course in their community if they were able to locate an instructor from the community who was qualified to teach the course, and if they were able to provide salary dollars for the casual instructors from their budgets. To date, two centres have delivered this course and several other centres have inquired about the possibility.

The second option explored was the development of a correspondence based program. A pilot module on medical interpreting was professionally videotaped in ten threehour lessons. Each lesson has two sections, each one and a half hours in length on medical content, and terminology development and role playing respectively. A manual to accompany the videotaped lessons has been developed to reinforce the material presented in the tapes. Self-administered quizzes are included for each lesson.

After every third lesson, students complete a written test on the medical content and terminology which they fax back to the program for marking. Each lesson contains a simulated doctor patient interview cassette tape based on material covered. This is used for interpreting practice by the students. Because of constraints imposed by our remote location and the vagaries of the Canadian postal system, no oral tests are administred until the end of the program. The final examination includes both written and oral sections. The Community Learning Centres administer the examination and then mail the material back to the program for marking. Students are encouraged to contact program faculty in Iqaluit by phone to discuss any problems they might encounter. A schedule of consultation times is designated at the beginning of the course.

As the course will not be offered in this new distance format until January 1991, it is not possible to provide an evaluation of these distance education materials at this time.

\section{0-1991}

Although the enrollment statistics for the 1989-1990 academic year were still low due to the factors discussed above, the increased enrollment of part-time students which reflected the redesign of the interpretation and translation module was quite significant. 
Seventy-five part-time students successfully completed the parts of the program in which they were enrolled, thus enabling us to better address some of the training needs of interpreter/translators in the Eastern Arctic. Although it is still too early to evaluate the results, we strongly believe that the other options developed, such as modified field delivery and correspondence-based programs, will further meet these needs and help address the training needs of students in more remote areas of our region. If successful, these options will be further expanded in the future.

\section{BIBLIOGRAPHY}

Arctic College (1990): Employee Handbook, Yellowknife, NWT.

Government of the Northwest Territories (1984): "Official Languages Ordinance", Northwest Territories Gazette, Vol. V, No. 2c.

Government of the Northwest Territories (1986): The Report of the Task Force on Aboriginal Languages, February 1986.

Government of the Northwest Territories (1986): Government of the Northwest Territories Response to the Recommendations of the Task Force on Aboriginal Languages, October 1986.

WLMAN, D. (1987): Report to the Donner Foundation on the Activities of the McGill University - Eastern Arctic Teacher Education Program, Montreal, McGill University. 